\title{
Kings, Creditors and Converts
}

\section{The Impact of Royal Policy and Corporate Debt on the Collective Identity of Majorcan Conversos after 1391}

\author{
Natalie Oeltjen* \\ University of Toronto
}

\begin{abstract}
Royal correspondence of the Kingdom of Majorca reveals that "external" economic factors and royal policies forced the first generations of 1391 conversos to remain a distinct social group. Not long after the anti-Jewish violence and mass conversions of 1391, the conversos of Majorca granted a percentage of their assets to King Joan I. At the same time, the conversos and surviving Jews had to repay the creditors of the former aljama, which had been dissolved following the attack against the Jewish quarter. These two collective financial obligations required the conversos to organize themselves as a group, following the precedent of the aljama, with elected leaders who organized an internal tax collection in order to pay these debts, and who lobbied on behalf of the conversos before the king and before their creditors. This administrative structure set the foundation for the converso confraternity of Sant Miquel, founded in 1404.
\end{abstract}

KeYwords: Crown of Aragon; Majorca; $15^{\text {th }}$ Century; History of the Jews; Converts; Communal Debt; Tax Burden.

REYES, ACREEDORES Y CONVERSOS: EL IMPACTO DE LA POLÍTICA REAL Y DE LA DEUDA CORPOrativa en la identidad colectiva de los conversos de Mallorca después de 1391.- Un examen detallado de la correspondencia real relativa a Mallorca muestra que factores económicos «externos» y directivas políticas reales obligaron a la primera generación de conversos de 1391 a permanecer como grupo social distintivo. Poco después de producirse la violencia anti-judía y las conversiones masivas de 1391, los conversos de Mallorca tuvieron que otorgar un porcentaje de sus propiedades al rey Juan I. Al mismo tiempo, conversos y judíos supervivientes debían seguir pagando los «censalers» de la aljama de judíos que había sido disuelta tras el ataque en 1391 contra la judería. Estas dos obligaciones financieras colectivas obligaron a los conversos a organizarse, siguiendo el precedente de la aljama, como grupo con líderes elegidos que administraron la colección fiscal interna a fin de pagar esas deudas, e interviniendo a favor de los conversos ante el rey y sus acreedores. Esta estructura administrativa puso los fundamentos de la cofradía conversa de Sant Miquel, establecida en 1404.

Palabras Clave: Corona de Aragón; Mallorca; siglo XV; historia de los judíos; conversos; deuda comunitaria; presión fiscal.

\footnotetext{
*noeltjen@chass.utoronto.ca
} 
It is well known that during the summer of 1391 violence erupted against Jewish communities across the kingdom of Castile and the Crown of Aragon that resulted in the loss of thousands of Jewish lives, and even more forced baptisms. In some cities like Barcelona, Girona, and Majorca, many baptisms occurred in the days or weeks after the violence. Additional conversions occurred in both kingdoms following the promulgation of anti-Jewish legislation in 1412-1414, and the edict of Expulsion in 1492. The mass baptisms of 1391 generated a new, separate social group, the conversos, ethnically and culturally distinct from the rest of the Christian population, but no longer Jewish. Despite the existence of some conversos who intermarried and integrated into Old Christian society, the majority belonged to endogamous, largely insular communities.

The subject of converso identity and culture has produced a vast and controverted body of scholarship, ${ }^{1}$ the majority of which deals with the late fifteenth through eighteenth centuries. Comparatively speaking, we know much less about the first few generations of conversos after 1391, and yet it was the experience of these first decades that, arguably, would give shape to future patterns of behaviour, and determine the trajectory of the conversos' shared identity and culture. There are also regional lacunae in the literature, in that the Crown of Aragon remains less well represented than Castile. Within the Crown of Aragon, the unique situation of Majorca's chuetas in the seventeenth through nineteenth centuries have attracted scholarly attention, ${ }^{2}$

${ }^{1}$ For overviews and critiques of the main issues and contributions to the debate over converso identity, see Norman Rотн, "Appendix A: Critical Survey of the Literature," in his Conversos, Inquisition, and the Expulsion of the Jews from Spain (Madison: University of Wisconsin Press, 1995), 363-371; David Graizbord, Souls in Dispute: Converso Identities in Iberia and the Jewish Diaspora, 1580-1700 (Philadelphia: University of Pennsylvania Press, 2004), 9-11; Yirmiyahu Yovel, "Appendix: Trends in the Literature," in his The Other Within: The Marranos; Split Identity and Emerging Modernity (Princeton: Princeton University Press, 2009), 389-404.

${ }^{2}$ On the chuetas, see Baruch Braunstein, The Chuetas of Majorca: Conversos and the Inquisition of Majorca (New York: Mennonite Publishing House, 1936); Francesc Riera Montserrat, Lluites antixuetes en el segle XVIII (Palma de Mallorca: Editorial Moll, 1973); Baltasar Porcel, Los Chuetas Mallorquines: quince siglos de racismo (Palma de Mallorca: M. Font, 1986); Angela SelKe, The conversos of Majorca: Life and Death in a Crypto-Jewish Community in 17 $7^{\text {th }}$ Century Spain (Jerusalem: Magnes Press, 1986); Enric Porqueres I Gené, Lourde alliance: mariage et identité chez les 
as has its prominent Jewish community up until $1391,{ }^{3}$ and to a lesser extent until 1435 when Jews were banned from living on the island; but the post-1391 conversos have not been well-studied, likely owing to the difficulty of the sources.

This paper fleshes out some of these historiographical gaps in its examination of the "administrative" transformation of Majorca's Jewish community into a converso community during the first two decades after the 1391 violence. It focuses on the economic exigencies which impacted converso life, specifically the effects of post-1391 royal policy and fiscal pressures in establishing, or reinforcing, the conversos as a collective separate from Old Christian society. Ultimately, this rather narrow scope allows for a broader examination of identity formation, and deliberately circumvents the more common discussion of religious observance and belief as markers of confessional identity. In addition to the cultural and religious affiliation of individuals, the following argues that the more "mundane" aspects of daily life such as finances, debts, institutions, government, and administration also had a profound effect on the nascent converso community. This case study illustrates conditions that existed in other communities within the Crown of Aragon, and should serve as an impetus for further comparative studies.

\section{The Anti-Jewish Violence of 1391 in Majorca}

Modern scholars have often attributed the 1391 violence in the Crown of Aragon to the increasing religious intolerance and clerical anti-Judaism concomitant with the friars' missionizing campaigns beginning in

descendants de juifs convertis à Majorque (1435-1750) (Paris: Kimé, 1995); Álvaro SAntamaría Arández, "Sobre la condición de los conversos y chuetas de Majorca," Espacio, Tiempo y Forma, Serie III, Historia Medieval 10 (1997), 219-262; Antoni Picazo Muntaner, Els Xuetes de Mallorca: grups de poder i criptojudaisme al segle XVII (Palma de Mallorca: El Tall, 2006).

${ }^{3}$ Lionel IsaAcs, The Jews of Majorca (London: Methuen, 1936); Antoni Pons PAstor, Los judios del reino de Mallorca durante los siglos XIII y XIV (Palma de Mallorca: M. Font, 1984); Antonio Contreras Mas, Los médicos judíos en la Mallorca bajomedieval: siglos XIV-XV (Palma de Mallorca: M. Font, 1997); Jorge Maíz Chacón, Los judíos de Baleares en la Baja Edad Media. Economía y política (La Coruña: Netbiblo, 2010). 
the thirteenth century. In the late fourteenth century, such virulent antiJudaism is manifest in the sermons of Ferrand Martínez, who is often cited as provoking the first mass baptisms and attack against the Jews of Seville. ${ }^{4}$ A second factor, recently propounded by Benjamin Gampel, is King Joan's failure to prevent or respond quickly to crush the outbreaks when they occurred. ${ }^{5}$ A third approach situates the anti-Jewish violence within the context of the popular revolts that erupted in many European cities in the late fourteenth century. An early proponent of this approach was Philippe Wolf, who demonstrated that the attack against the Jews in Barcelona was one component of a lower-class uprising against the municipal administration -incited, he suggests, by news of the revolt in Majorca. ${ }^{6}$ The late nineteenth-century Majorcan scholar Jose María Quadrado discussed the attack against the Jews in the context of local class conflict and popular rebellion, but only recently has this approach been deliberately asserted by local scholars, with more detailed investigations of how taxation and public finances exacerbated the island's social tensions. ${ }^{7}$ While anti-Jewish preaching and a weak king were certainly

${ }^{4}$ One of the first to write about Martínez and 1391 was Henry Ch. LEA, "Ferrand Martínez and the Massacres of 1391," AHR 1 (1896), 209-219. On thirteenth-century missionizing, see David Berger, "Mission to the Jews and Jewish-Christian Contacts in the Polemical Literature of the High Middle Ages," AHR 91 (1986), 576-591; Jeremy CoHen, The Friars and the Jews: the Evolution of Medieval Anti-Judaism (Ithaca: Cornell University Press, 1982); Robert CHAZAN, Daggers of Faith: Thirteenth-Century Christian Missionizing and Jewish Response (Berkeley: University of California Press, 1989).

${ }^{5}$ Benjamin GAMPEL, “'Unless the Lord Watches over the City...', Joan of Aragon and his Jews, June-October 1391," in Elisheva CARLEBACH and Jacob J. SCHACHTER (eds.), New Perspectives in Jewish-Christian Relations in Honor of David Berger (Leiden-Boston 2012), 65-89.

${ }^{6}$ Philippe WolfF, "The 1391 Pogrom in Spain: Social Crisis or Not?," Past and Present 50 (1971), 4-18. Paul FreEdMAn also referred to the peasants' involvement in the 1391 revolts in his The Origins of Peasant Servitude in Medieval Catalonia (Cambridge: Cambridge University Press, 1991), 182.

7 José Maria Quadrado. Forenses y ciudadanos: historia de las disensiones civiles de Mallorca en el siglo XV (Palma: Estevan Trias, 1847), 95-96; Josep F. LóPEZ BonET, "La revolta de 1391: efectivament crisi social," in XIII Congrés d'Història de la Corona d'Aragó, Comunicacions, I. El regne privatiu de Mallorca i la Mediterrània (Palma de Mallorca: Institut d'Estudis Baleàrics, 1989); IDEM, "Consideracions sobre l'assalt al call de ciutat de 1391," in Sobre jueus i conversos de les Balears (Palma: Leonard Muntaner, 1999), in which he critiques Quadrado's narrative of 1391; Jorge Maíz Chacón, “Apre- 
important factors, in Majorca, wider social and economic tensions are critical to understanding the violence and ensuing dynamics between the remaining Jews, conversos, and the Old Christian population. The role of class conflict in Majorca contrasts sharply with other places such as Valencia, where a religious, conversionist rhetoric permeated the events and subsequent narratives to a much greater extent, and where the revolt was prompted, in part, by anti-Jewish preaching and violence in Castile.

In the early morning hours of August 2, 1391, a large, angry crowd of peasants hailing from the island's rural towns converged outside the city walls. When the governor, Francesc Sagarriga, marched out to meet them with his retinue, the mob wounded his horse and killed the horse of one of his counselors, forcing him to retreat. ${ }^{9}$ The city bailiff, Lluis de Belviure, soon took over leadership of the rebellion, inciting the mob to attack the Jewish quarter, the call, after which they pillaged the houses of municipal counselors, the city hall, and agricultural lands surrounding the city walls that were owned by urban elites. ${ }^{10}$ It was probably during the attack on the

ciaciones sobre la part forana. Mentalidad y marginalidad en el siglo XIV mallorquín (1391)," Mayurqa 28 (2002), 241-248; Maria Teresa Ferrer i Mallol, "Conflictes populars a Mallorca a la fi del segle XIv," Estudis Baleàrics 84/85 (2006), 87-98. On 1391 in the Crown of Aragon more broadly, see Jaume RIERA I SANS, "Los tumultos contra las juderías de la Corona de Aragón en 1391," Cuadernos de Historia. Anejos de la revista Hispania 8 (1977), 213-225.

${ }^{8}$ The attack on the Valencian Jewish quarter occurred on July 9, 1391. The account provided by the jurats "sacralized the anti-Jewish violence," claiming that the baptismal font had miraculously refilled itself after the conversion of masses of Jews. Mark D. MEYERSON, A Jewish Renaissance in Fifteenth-Century Spain (Princeton: Princeton University Press, 2004), 26. Norman Roth, on the other hand, contends that the violence was a result more of "social and political factors" than religious anti-Judaism, "such as the desire to destroy documents of debts due to Jews, and economic jealously." Norman Rотн, "1391 in Aragón, Catalonia, Valencia, and Majorca," Iberia Judaica 3 (2011), 49-75: 52.

${ }^{9}$ Quadrado wrote that the governor and urban elites at this point fled to the castle of Bellver, about three kilometres from the city. See his Forenses y ciudadanos, 97. However, this rendition is not adopted by other historians. According to Lopez Bonet, the governor did not go to Bellver until August 11 and previously took shelter in the city's royal castle, the Almudaina. See his "La revolta de 1391," 11.

${ }^{10}$ Pablo Piferrer, José Maria Quadrado, Islas Baleares (Barcelona: Cortezo, 1888), 214. Following the initial attack on the city, Bellviure allegedly rounded up rural bailiffs to participate in the rebellion. Subsequently he escaped via Sóller to Menorca where, by September, he was caught attempting to flee on a Venetian ship. He was brought to 
Jewish quarter that the city's artisans, together with other citizens, joined in the plunder. Depending on which of the two contemporary sources one consults, between 180 and 300 Jews were murdered. ${ }^{11}$ Reportedly 800 took refuge along with the governor in the city's royal castle, the Almudaina, while others, presumably, converted on the spot. ${ }^{12}$ Many fled the island altogether. The long standing commercial relationships that elite Majorcan Jews had fostered with North African port cities, as well as the close, yet complicated, relationships with powerful Christian elites on the island, enabled many Jews to escape the violence by sailing southward across the Mediterranean to the Muslim Maghrib. This emigration continued for many years afterwards, notably by conversos seeking to return to Judaism - a crime for which, in a Catholic kingdom, one would be burned at the stake as an apostate. ${ }^{13}$

Barcelona where he was tried and executed by decapitation for his leading role in the rebellion (Ferrer i Mallol, "Conflictes populars a Mallorca," 94; see also Pons PAstor, Los judíos del reino de Mallorca, II, 315, no. 138).

${ }^{11}$ Quadrado wrote that 300 Jews were killed, based on the account of the Majorcan notary Mateu Salzet (Forenses y ciudadanos, 97). Salzet's account is published in Campaner's Cronicon Mayoricense (Palma, 1881), 126-127. The original notarial registers are housed at the Arxiu Capitular de Mallorca, and contain notes on events that took place at the time he was writing. The other source is an anonymous "noticiari" (ARM RP 2048). The latter notary wrote that the attack on the call lasted from 3am until 10am; Salzet wrote that it began at $2 \mathrm{am}$. Cf. Pons Pastor, Los judios del reino de Mallorca, II, 165; LóPez Bonet, "La revolta de 1391," 122, notes 8-9.

${ }^{12}$ In his letter regarding the massacres of 1391, Hasdai Crescas stated that in Majorca 300 people died, 800 took refuge in the royal castle, and "the others changed their faith." Franz KoBler, Letters of the Jews through the Ages (London: Ararat Publication Society, 1952), 273. Pons Pastor also writes that 800 Jews took refuge in the royal castle (Los judios del reino de Mallorca, 166). Although Yitzhak F. Baer also believes that a number of Jews would have been forcibly converted during the violence of August 2, I have not seen any documentation of Majorcan conversos in archival records until October 1391. See A History of the Jews in Christian Spain (Philadelphia: JPSA, 1966), vol. II, 102.

${ }^{13}$ Royal administrative correspondence refers to the problem of Jews and conversos leaving the island in 1391 and afterwards to such an extent that the numbers must have been significant. Most of them, like the renowned Majorcan rabbi Simon ben Zemach Duran, probably gave away what valuables they could carry with them as bribes at the port. On Duran and 1391, see Rотн, "1391 in Aragón, Catalonia, Valencia and Majorca," 55, note 33). Indeed, later King Joan chastised a port official for taking the goods of people fleeing the Jewish quarter, and allowing conversos to leave the island to "return to Judaism." (ACA CR 1998, 63v-64r, June 3, 1395). 
The sources report either 3 or 300 Christians killed. ${ }^{14}$ The death of 300 Christians may seem exaggerated at first, but not so when we consider that the 1391 violence against the Jews in Majorca was just one part of a wider agrarian and working class revolt against the urban patriciate. The rebels' main grievances surrounded the fiscal exploitation of rural and artisan classes by ruling elites, and the underrepresentation of the former in the island's government. Their complaints against the Jews were specifically related to "usury." The rural classes in particular had become deeply indebted to Jews in order to make ends meet between increasing taxation, plague and poor harvests during the economic downturn of the late fourteenth century. For a decade prior to the revolt, Majorca's forans (inhabitants of rural parishes) and menestrals (artisans) had been petitioning the Crown for greater representation on the island's Consell (government) but without much success. ${ }^{15}$ They complained that the urban elites, who unjustly held the balance of power, were corrupt and imposed excessive taxes which were financially crippling the island's inhabitants.

In September 1390, at the same time that Majorca's menestrals and forans were presenting their grievances before the royal court concerning the injustices and taxation imposed by the jurats, the latter promised the king a subsidy of 11,500 florins (no doubt in exchange for certain political benefits such as keeping the balance of power to their advantage), which required them to raise the city's public debt and impose even more taxes on the island's inhabitants. ${ }^{16}$ Rather than provide the king with the money directly, the municipality was to pay his chief creditor, the Saragossan merchant and later treasurer to the queen, Berenguer de Cortilles, who had already advanced the funds to the king. Paying Cortilles involved a complex set of transactions that granted him a substantial role in Majorcan finances, including temporary control of the island's mint. Mean-

${ }^{14}$ Quadrado, Forenses y ciudadanos, 97. cf. Pons Pastor, Los judios del reino de Mallorca, II, 165; LóPez Bonet, “La revolta de 1391," 122, notes 8-9.

${ }^{15}$ Ferrer i Mallol, "Conflictes populars a Mallorca," 88, 91.

${ }^{16}$ José Francisco López Bonet, "Para una historia fiscal de la Mallorca Cristiana (siglos XIII-XIV)," AEM 38 (2008), 176-177; IDEM, "Els deutes del rei Joan i el regne de Mallorca," in El credit i el sistema financer del regne de Mallorca (segles XIV-XV) (Palma: Universitat de les Illes Balears, Consell de Mallorca, 2009), 101-126; IDEM, "La revolta de 1391," 112. 
while, the negotiations between representatives of the ciutadans, menestrals and forans that continued on-and-off at the royal court through 1390 and 1391 were brought to a halt, unresolved, when the revolt broke out in Majorca and other cities on the peninsula. ${ }^{17}$

What is important about all this, aside from illustrating the social tensions leading up to the 1391 rebellion which had little or nothing to do with Jews, is the following: First, that King Joan was deeply indebted to Berenguer de Cortilles, among other creditors, and the king had arranged to repay Berenguer at least partly through Majorcan revenues. $^{18}$ The second important observation here is that King Joan made imprudent decisions in order to prioritize his most immediate financial needs, as he did by granting Majorca's jurats the authority to impose additional taxes so that he could repay his debt to Berenguer, at a time when popular unrest was fomenting on the island precisely as a result of fiscal exploitation.

Without dismissing the virulent anti-Judaism or underplaying the catastrophic significance of the rebellion for the Jews, we can still bear in mind that what mattered most for the rebels was their fiscal oppression -an oppression which ultimately resulted from the Crown's constant solicitation of financial contributions from the cities, aljamas and Corts. The uprising against the city that began on August 2 continued for another two months. Threatened by a makeshift rebel "army" four thousand strong, the jurats were forced to make certain concessions on August 27, including abolishing all usurious debts owed to Jews or Christians. After a revamped army of forans attacked the castle of Bellver on October 2, where elites had taken refuge, the governor commissioned the bishop's representative, the vicar general, to negotiate with the rebel faction on behalf of the citizens. These negotiations resulted in the promulgation of 56 statutes on October 4 granting the political and fiscal reforms demanded by the rebels as a condition for a truce. This lengthy list of reforms referred to Jews only in two respects. The first reiterated the rebels' earlier demand to

\footnotetext{
${ }^{17}$ Ferrer i Mallol, "Conflictes populars," 92-93. On Cortilles see López Bonet, "La revolta de 1391," 118.

${ }^{18}$ On Mallorca's financial commitments to King Joan and the latter's debt to Cortilles, see López Bonet, "Els deutes del rei Joan,” 101-126.
} 
abolish usurious debts to Jews, as well as to Christians. The second was new, and demanded that within eight days, the Jews convert or be killed.

It is surely no coincidence that the issue of conversion was not raised explicitly until negotiations between the forans and ciutadans were brokered by a prominent member of the clergy. ${ }^{20}$ The jurats, presumably desperate to appease the rebels, promised the Jews that they would pay 20,000 pounds of their corporate debt if they converted. Although the jurats never fulfilled their promise, arguably there was no other option for the 800 Jews that had been living in the royal castle since August 2. The majority of conversos, then, were baptized sometime between October 4 and 21, when they begin to appear in archival records. ${ }^{21}$

That Jews converted on the promise of having their debt cleared merits further discussion. The concept was an old one, present in the late antique Roman legislation that influenced medieval jurisprudence. The Justinian code, for instance, stipulated that Jewish converts to Christianity be freed from paying their debts. ${ }^{22}$ In the Crown of Aragon from the 1380s,

${ }^{19}$ For a summary of the capitols see LÓPEZ BonEt, "La revolta de 1391," 116.

${ }^{20}$ Similarly, in Girona, Jews were given refuge in the nearby castle of Gironella and in September the pobla menuda, comprised mainly of peasants, lay siege on the castle and demanded that the Jews there be converted. According to Baer, "[a]mong the instigators were the monks" (A History of the Jews, II, 106-107). On the 1391 violence in Girona see Jaume RiERA I SANS, "Els avalots del 1391 a Girona," in Jornades d'història dels jueus a Catalunya (Girona: Ajuntament de Girona, 1987), 95-159.

${ }^{21}$ Subsequently, King Joan wrote to the governor of Majorca requesting a copy of the decision of the jurats and the Gran Consell de Mallorca to help the aljama pay its debts. The document indicating the promise of the jurats is published in Pons Pastor, Los judios del reino de Mallorca, 323, no. 131 (ARM, Suplicacions, March 14, 1392); and in Boletín de la Real Academia de la Historia 40 (1902), 152. The king also requested a copy of a letter written to him by the jurats asking that the Jews in the royal castle be baptized, and another letter written to him by the forans demanding that the "Jews in the royal castle become Christians within eight days or die" (ACA CR 1995, 66v, March 20, 1392). The earliest documentation I have found referring to conversos in Majorca is the governor's order of October 21,1391, that all converts declare whether they plan to keep their houses in the Jewish quarter (ARM AH 419, 57 bis), publ. Boletín de la Sociedad Arqueológica Luliana $[=$ BSAL] 8 (1899), 441.

${ }^{22}$ Amnon Linder, Jews in Roman Imperial Legislation (Detroit: Wayne State University Press; Jerusalem: Israel Academy of Sciences and Humanities, 1987), 80, 199200, 214-215. The Summa Perusina, a seventh-century epitome of the Justinian code, 
some newly baptized Jews successfully petitioned the king to free them from paying their debts in consideration of their conversion. ${ }^{23}$ Encouraging conversion through the promise of material benefits, in general, was commonly advocated by Christian authorities as far back as Gregory the Great. A number of early medieval legal codes protected converts from being disinherited by their Jewish families. ${ }^{24}$ Notwithstanding these precedents, there was also a secular legal tradition to the contrary, which dictated that converts be stripped of their pre-baptismal property altogether. Many medieval European kings declared that Jewish converts lost their inheritance rights, and in some cases, the Crown appropriated their property. ${ }^{25}$ The Third Lateran council (1179) threatened to excommunicate those who did not restore the goods and inheritance of a convert, but this injunction probably achieved limited success. ${ }^{26}$ In line with papal policy, to encourage conversion and prevent relapse, King Jaume I of Aragon issued decrees allowing converts to retain their property and inheritance. ${ }^{27}$

reiterates an earlier law absolving Jewish converts to Christianity of their debts or crimes. However, in 397 Emperors Arcadius and Honorius sought to prevent this practise, ruling that Jews should not seek asylum from creditors by fleeing to churches, pretending to convert, and therefore had to pay their debts before being baptised.

${ }^{23}$ Alexandra Guerson, "Seeking remission: Jewish conversion in the Crown of Aragon, c. 1378-1391," Jewish History 24 (2010), 33-52: 37-45.

${ }^{24}$ Solomon Katz, "Pope Gregory the Great and the Jews," JQR 24 (1933), 113-136; Dwayne E. Carpenter, Alfonso X and the Jews: An Edition of and Commentary on the Siete Partidas (Berkeley: University of California, 1986), 79. Regarding legal sources that protect the convert from disinheritance see LINDER, Jews in Roman Imperial Legislation, 79; e.g. under Valentinian III (426); cf. IDEM, The Jews in the Legal Sources of the Early Middle Ages (Detroit: Wayne State University Press; Jerusalem: Israel Academy of Sciences and Humanities, 1997): e.g. under Reccared I (588); and in a lesser known text called Scintella from Orleans or Tours $\left(8^{\text {th }}-9^{\text {th }}\right.$ C. $)$.

${ }^{25}$ Solomon Grayzel, The Church and the Jews in the XIII Century (Philadelphia: The Dropsie College for Hebrew and Cognate Learning, 1933), 19, note 36. In the Disputation of Majorca (1286) the protagonist, reminds his Jewish interlocutor that if he converts, he will be in the greatest poverty. Inghetto Contardo, Disputatio Contra Iudaeos, ed and trans. Gilbert DAHAN (Paris: Les Belles Lettres, 1995), 23-24, 261.

${ }^{26}$ Third Lateran Council (1179), Canon 26, in Raymonde ForeviLle, ed. Latran I, II, III et Latran IV (Paris: Editions de L'Orante, 1965), 222.The same canon states that converts ought to be in better [material] circumstances than they were before baptism.

${ }^{27}$ Grayzel, The Church and the Jews, 19, note 36; 254-257, no. 105; The Siete Partidas also protected convert's property. 
Notwithstanding their official adherence to this policy, it seems that his successors did not always act in accordance with it. For instance, certain converts successfully protested Jaume II's confiscation of their property on the basis of his prior renewal of Jaume I's decree. ${ }^{28}$ As late as 1389 , Isaac Golluf requested confirmation from King Joan I that his property would not be seized if he converted. ${ }^{29}$ This does not demonstrate conclusively that the king would have done so, and Isaac's request may have had more to do with family politics. What it does suggest is that converts could not take for granted the security of their property.

\section{Jews, Conversos and the Royal Patrimony in 1391}

King Joan's reign was characterized by financial instability and administrative weakness. Even before the 1391 revolts the Crown suffered financial troubles. Maintaining its presence in Italy was a large expense, and when municipalities did not come through with the funds promised for a much-needed expedition to Sardinia, Joan turned to courtier-creditors such as Berenguer de Cortilles. There was also the king's costly penchant for courtly leisures: the arts, gourmet food, and hunting. When the anti-Jewish violence erupted across the kingdom, King Joan did not act quickly enough to suppress it, preoccupied instead with his pregnant queen's health and plans for his next hunting excursion. ${ }^{30}$ He was, however, much more diligent in capitalizing on the revolts after the fact. His letters express understandable anxieties over the "damage" they caused to the royal fisc, but rather than investing in long-term goals such as reviving the kingdom's devastated Jewish communities, educating and integrating the new converts, or even addressing wider social tensions, King Joan's initial responses to the violence focused conspicuously on its revenue potential.

\footnotetext{
${ }^{28}$ Guerson, "Seeking remission," 41-42.

${ }^{29}$ Guerson, "Seeking Remission," 42; BAER, A History of the Jews, 93.

${ }^{30}$ Gampel discusses King Joan's response to the 1391 anti-Jewish violence in “"Unless the Lord Watches over the City'." For a more detailed history of Joan's reign, see Rafael TAsis i Marca, Joan I, el rei caçador i music (Barcelona: Editorial Aedos, 1959), especially 195-209. For a general characterization of King Joan's reign see Thomas N. Bisson, The Medieval Crown of Aragon: a Short History (Oxford: Clarendon Press, 1986), 120-125.
} 
First, he imposed fines on those who participated in the assaults, promising these anticipated revenues as collateral for loans and as salaries for high officials. He promised one quarter of the revenues from all punishments related to the avalots throughout the kingdom as part of his daughter's dowry to marry Louis of Anjou. ${ }^{31}$ In Majorca, he secured a loan of 1,300 gold florins from his procurator Berenguer Llobet on revenues anticipated from the punishments of local rebels. ${ }^{32}$

A second revenue source was the confiscation of all assets belonging to conversos who fled the kingdom, and fines of those caught en route, since these conversos were reasonably presumed to be headed for North Africa where they would renege on Catholicism and return to Judaism. ${ }^{33}$ Following the revolt, the king had banned all converso travel, but eventually made it possible for them to leave the island for a limited period if they purchased a royal license and secured guarantors. Many conversos simply did not return, leaving their guarantors to face huge fines. By confiscating the property of illegal exiles, King Joan acquired some large, opulent homes with gardens and running water, which later he granted to officials or creditors to whom he was indebted. ${ }^{34}$

The king did not only confiscate the assets of individuals. A third income source was the Crown's appropriation of the collective assets of the former aljama. Here it is critical to distinguish the aljama, the corporate body of Jews that was a legal entity of its own, as opposed to the surviving Jewish community, which was not an institutionalized

${ }^{31}$ ACA CR 1979, 162v-163v (April 22, 1392). Similarly, in February 1392 King Joan ordered his officials to repay a loan of 500 florins to his butler Pere Morató through fines stemming from the avalot (Pons PAstor, Los judios del reino de Mallorca, II, 322, no. 140). The following July he ordered another 10,000 florins to be paid to Francesc Morató, also a familiar of the court, from the same revenues (ACA CR 1979, 181r-v, July 7, 1392).

${ }^{32}$ ACA CR 1995, 92r-94r (May 8, 1392).

${ }^{33}$ The right of a king to appropriate the all goods of a Judaizer -a Jewish convert to Christianity who engages in Jewish observances- can be found in Visigothic Law, issued under King Erwig (Linder, The Jews in the Legal Sources of the Early Middle Ages, 294).

${ }^{34}$ For instance, in December 1391 Joan allocated 1,000 gold florins from "from those goods of conversos who left Majorca without a license and fled to Sarracen lands" to pay his debt to his councillor, Umbert de Fonollar (ARM AH LR 39, 65r-v, April 18, 1392). 
group. Royal letters repeatedly refer to the "dissolution and destruction of the aljama" after the revolt. This meant that even though there were still Jews living on the island, there was no longer a legal corporate entity, a semi-autonomous institution with its own leadership, judicial system and fiscal administration that was endorsed by the Crown. While the king would have officially dissolved the aljama because of low numbers and since most of the elites who had comprised its administration had converted or fled, dissolving the aljama also gave the king major assets which he could use towards his financial obligations. Since Jews belonged to the Crown, the Crown had a legal claim over all ownerless Jewish property, including communal property. Once the aljama ceased to exist, King Joan could justify appropriating its communal assets, which included valuable real estate like synagogues, the butchery, cemetery or schools, as well as the pensions that funded various charities. The king also appropriated the communal goods of the dissolved aljamas of Barcelona and Valencia, distributing those, too, among officials to whom he was indebted. ${ }^{35}$ In Majorca, the king granted most of the communal assets to Berenguer

${ }^{35}$ Xavier Pons i Casacuberta, "La comissió creada pel rei Joan I i la reina Violant a partir dels pogroms contra els jueus del 1391. Espoliació del capital i patrimoni dels jueus i conversos," Acta Historica et Archaeologica Mediaevalia 30 (2009-10), 119-152: 125. King Joan also appropriated the collective assets of the Valencian aljama and explicitly forbade these from being used to repay its own debts since these pertained to the royal couple: "com aquelles son dels dits senyor e senyora e'ls pertanguen en plen dret e senyoria e proprietat," José Hinojosa Montalvo, The Jews of the Kingdom of Valencia: from Persecution to Expulsion, 1391-1492 (Jerusalem: Magnes Press, 1993), 394, no. 123. In each of these cities, Joan appointed officials to handle the collection and redistribution of communal assets. In Majorca, in January 1392 he comissioned Bernat Calopa and Jaume Pastor, officials of the royal treasury, together with Violant's treasurer Guillem de Montbru, to handle the "administration and recovery of the goods of the aljama, namely to reclaim debts to the aljama, its communal accounts, synagogues, charities and confraternities, and all the goods of each and every Jew, and to deal with any lawsuits if necessary" (ACA 1995, 35r-36r, January 7, 1392). Royal correspondence later in the year refers only to Jaume Pastor and Guillem de Montbru as managing the collection of communal goods of the former aljama and also "the vacant goods of its individuals" -probably referring to royal confiscations of the property of Jews who died intestate or fled- (ACA CR 1995, 78r, nd; cf. ibid., 75r, April 16, 1392). 
de Cortilles, ${ }^{36}$ but also to other prominent members of the royal administration. $^{33}$

Given King Joan's short-sightedness combined with his desperate financial situation, it should come as no surprise that he used the former aljama's assets for his own immediate benefit instead of employing them to support the new converso community, or to resurrect the Jewish one, which would have had financial benefits in the long term. The fiscal losses entailed by the destruction of aljamas in 1391 motivated the separate, albeit failed, attempts of Kings Joan and Martí to re-establish the aljamas of Majorca, Barcelona and Valencia in later years, once Joan had already dismantled them and stripped them of their assets. ${ }^{38}$ Where there was no longer an aljama, there was no longer an organizational structure in place to administer local tax collections, but the revenue-generating capacity of many surviving Jewish communities had been, in any case, dramatically reduced after the revolts. The tax revenues, loans and subsidies from Jewish aljamas had long been an integral component of royal finances which King Joan could not afford to give up, nor would he exactly: Joan's treatment of Majorcan conversos suggests that, in the short term at least, he simply substituted lost Jewish revenue with revenue derived from conversos. Fiscally speaking, King Joan still related to the conversos as his Jewish patrimony.

${ }^{36}$ ACA 1997, 139v-140v (October 1, 1394); this letter states that the grant was made to Cortilles at an earlier time but doesn't state when exactly; it may have been some time in 1393, after the king had ordered the Jewish quarter "opened up" -in other words, for the gates to be torn down- so that the area and its buildings would be more palatable to Christian buyers, cf. ACA 1996, 37r, October 31, 1392.

${ }^{37}$ For instance, in 1393 Joan granted the butchery to Antoni Rexach, also of his treasury, in gratitude for his services (ACA 1996, 149r-v, August 1, 1393).

${ }^{38}$ King Joan made various overtures in the hopes of resurrecting the Majorcan aljama. For instance, by allowing Jews to travel to North Africa to collect their merchandise (ACA CR 1995, 3r, August 19, 1391); inviting 150 Portuguese Jews to settle in Majorca (ARM AH G5, 69r, March 26, 1395); granting immunity from any litigation or financial obligations to Jews who came "to live and trade" in Majorca from other parts of the Crown of Aragon, or from any other kingdom (ACA 1910, 151v, October 17, 1395, published in Fritz BAER, Die Juden im christlichen Spanien. Urkunden und Regesten. Aragonien und Navarra (Berlin: Akademie Verlag, 1929), 724-726, no. 461; reproduced verbatim in Martí's confirmation of it: ACA CR 2264, 7r-8v, July 19, 1397); Later, King Martí ordered his procurator in Majorca to take new (and final) initiatives to resurrect the aljama (ACA CR 2264, 140r-v, August 20, 1399). For attempts to re-establish the aljamas of Barcelona and Valencia see ACA CR 2039, 170v-171r, published in BAER, Aragonien, 712-713, no. 453. 
There is a hint of this continuity in the ways he directed the assets confiscated from baptized Jewish exiles to pay for the costs of sending military reinforcements to Sicily, evoking the Crown's past practice of using Jewish subsidies to fund the occupation of Sardinia and Sicily. ${ }^{39}$ In 1389 and earlier, King Joan had compelled the Majorcan aljama to borrow money in order to pay the costs of his administration in Sardinia. ${ }^{40}$ When there was no longer an aljama to extract funds from, in 1395, he ordered the transfer of revenues from confiscated loans originally owed to conversos to the noble Francesc Sa Garriga who was headed to Sicily with the captain of the royal armada. ${ }^{41}$

\section{Fiscal Obligations of the Conversos After 1391}

\subsection{The Donatio}

There was a more overt indication of the fiscal continuity between Jews and conversos, and another source of revenue stemming indirectly from the revolt. Following the baptisms, representatives or procuradors of the community of Majorcan conversos committed to pay a large sum of money to King Joan, referred to as a donatio ('donation') in royal letters. ${ }^{42}$ The value originally promised was four sous per pound (a rate of 20\%) to be collected from all their goods, ${ }^{43}$ although after some negotiation

${ }^{39}$ See Yom Tov Assis, "Jewish Capital and the Conquest of Sardinia by the Catalans," Italia 9 (1990), 7-18.

40 ACA CR 1872, 175r-v (nd, 1389).

${ }^{41}$ ACA CR 1997, 169v-170r (January 28, 1395).

${ }^{42}$ I will refer to this grant as the donatio in order to be faithful to the language used in the archival sources. It is not clear whether the term was used deliberately given the legal definition employed by notaries at the time, i.e. a totally free gift, as opposed to a transaction that imposed obligations on both parties. In practice the donatio might have belonged to the latter class, i.e. a cessio (a term used in some of the sources together with donatio -e.g. donatio et cessio). Often the sources replace the term donatio simply with "the four sous per pound."

${ }^{43}$ ACA CR 1995, 138v-139r (August 9, 1392). This letter refers to the prior concession of the donatio. The date of the original concession is not indicated; just that it was made "after the destruction of the call." 
the $20 \%$ was levied just from the conversos' loan investments. ${ }^{44}$ In 1392 King Joan commissioned Berenguer de Cortilles to oversee the collection of the donatio in Majorca, ${ }^{45}$ which probably meant that the king was repaying part of his debt to Berenguer through the four sous per pound. The conversos of Valencia, and of Barcelona made similar grants to the king, although at a rate of about $17.5 \%$ of all their goods. ${ }^{46}$

The sources do not explicitly tell us why the conversos would make this large grant in the wake of such destruction and economic loss, but we can hypothesize. Prior to 1391 the aljama of Majorca, like other aljamas in the kingdom, was taxed separately from the rest of the Christian population and at much higher rates, but in exchange received special protections from the king who needed to preserve the economic well-being of his Jewish "treasure." Just as Jewish communities typically received royal protection and privileges in exchange for their fiscal servitude, so too the conversos may have stood to gain something in exchange for the donatio. ${ }^{47}$ Indeed, King Joan did declare that the conversos were under royal protection. ${ }^{48}$ Furthermore, if the king did have legal precedent to appropriate the goods of baptized Jews, as discussed above, it is possible that the conversos granted the donatio in exchange for the privilege to retain their property -but this

${ }^{44}$ ACA CR 1996, 40v-41r (November 23, 1392).

${ }^{45}$ ACA CR 1996, 36v-37r (November 8, 1392).

${ }^{46}$ For Valencia, ACA CR 2001, 27r; for Barcelona, The Jews in the Crown of Aragon: Regesta of the Cartas reales in the Archivo de la Corona de Aragón. Part II (1328-1493), compiled by M. ${ }^{a}$ Cinta MAÑ́ \& Gemma Escribà (Jerusalem: The Hebrew University of Jerusalem, 1995), 250, no. 1223. Other towns also made grants to the Crown. In Burriana, the conversos made a donationem et concessionem to the royal couple of twelve diners per pound of all their goods, and in November 1392 the king allowed them to sell their real estate in order to pay it. In exchange for their donatio, the king granted a general pardon and safeconduct to the conversos of Burriana (Hinojosa Montalvo, The Jews of the Kingdom of Valencia, 383, no. 108; 387, no. 114).

${ }^{47}$ Hinojosa Montalvo, The Jews of the Kingdom of Valencia, 387.

${ }^{48}$ ACA CR 1995, 59v-60v (March 1, 1392); ACM LR 39, 103r-v (July 7, 1392). In this sense the donatio is analogous to the subsidies promised to the Crown by other corporate groups, such as communities of foreign merchants, in exchange for certain privileges or protection. David Abulafia compared the "privileged position" of the Jews of Majorca to the other communities there, such as the Genoese, cf. his A Mediterranean Emporium: the Catalan Kingdom of Majorca (Cambridge: Cambridge University Press, 1994), 77. 
suggestion must be made with caution since it is not explicitly indicated in the sources themselves.

If we hypothesize based on the language of the archival sources alone, the most likely (though not necessarily exclusive) reason for the donatio is that it was meant to pay for the practical assistance of royal administration. King Joan instructed his royal procurator, Mateu de Llosch, to pay for the administrative costs of attempting to recover and restore the goods stolen from the Jewish quarter during the revolt with "the four sous per pound." ${ }^{49}$ There were also administrative costs involved in collecting the conversos' loans, from which the donatio was to be paid. Moneylending, in fact, was a critical sphere in which Jews had typically depended on royal beneficence prior to 1391 . For instance, aljamas did not hesitate to enlist the help of royal officials in enforcing the payment of debts. Like their counterparts across the Crown of Aragon, Majorcan Jews had invested a significant portion of their capital in loans primarily to the forans. Following the 1391 rebellion, the creditors, most of them now converts, needed to recover their capital from rural debtors who surely participated in the sack of the Jewish quarter. Considering, moreover, that indebtedness to Jews had been a grievance among the rebels, it would only seem prudent for conversos to commission royal authorities to take over the frustrating and potentially dangerous task of pressing their indignant debtors for repayment. It was probably the assistance of royal officials that King Joan was referring to when he wrote, in one of his letters concerning the donatio, that the conversos had offered it "so that their loans would be more easily collected." ${ }^{50}$ For his part, the king had a strong incentive to ensure that these loans were collected, since $20 \%$ was automatically siphoned off to pay the donatio. ${ }^{51}$

\footnotetext{
${ }^{49}$ ACA CR 1998, 57v (March 20, 1395).

${ }^{50}$ ACA CR 1997, 176v-177r (February 15, 1395); see also 1996, 40v-41r (November 23, 1392).

${ }^{51}$ The first extant local announcement concerning the donatio that I have found is dated July 1392, instructing notaries to cancel letters of debt owing to conversos only after the latter had paid the dret of four sous per pound. The governor also stipulated that debtors had to repay their debts "until the dret was paid" (ARM AH 419, 92r, July 2, 1392), also published in BSAL 8 (1899), 443. Even if a debtor obtained a moratorium, he had to pay the four sous per pound -i.e. $20 \%$ value of the debt- right away. For instance, in August 1392 the converso Gabriel Fuster, formerly called Moxi Natjar, agreed upon
} 
One cannot ignore the fiscal connotations of the term donatio either, which in the fourteenth-century could refer to a kind of subsidy or tax. ${ }^{52}$ Even if it was not intended as such, in practical terms, the donatio functioned like a de facto tax, ${ }^{53}$ and may well have set a precedent for royal "taxation" of conversos a century later. In 1495 King Ferdinand of Aragon negotiated with a representative of the former Jews of Sicily to allow returning converts, who had fled local persecutions in 1494 , to reclaim their property on the condition that they pay a $45 \%$ tax. In Provence, after forced conversions during the same period and the expulsion of Jews in 1500, King Louis XII separately taxed all Jewish converts to Christianity in order to pay military costs. ${ }^{54}$ The Portuguese New Christians, too, were collectively taxed early in the sixteenth century. ${ }^{55}$ What these examples have in common with the donatio, and what is worth noting despite the century gap between them, is that the Crown collected a sum from a corporate body of conversos, represented by leaders who negotiated with the king on their behalf.

a payment scheme with his debtor Jaume Joan of Manachor: Gabriel remitted 7 of the 32 pounds that Jaume owed him, but Jaume had to pay 4 pounds immediately "to those delegated by the king to receive four sous per pound from the debts of the conversos," and the remaining 21 pounds in two instalments (ARM AH 64, 22v; February 7, 1392).

${ }^{52}$ See the entry for donatio in Du CANGE, et al., Glossarium medice et infima latinitatis (Niort: L. Favre, 1883-1887), < http://ducange.enc.sorbonne.fr/DONATIO>: "Præstatio quævis, tributum, quod sub donationis ultroneæ titulo domino præstatur." The derivative term donativo was used in Sicily to denote a tax under Federico III d'Aragona, cf. Guiseppe Di Martíno, Il sistema tributario degli Aragonesi in Sicilia (1282-1516) (Palermo: Edizioni Librarie Siciliane, 1990), 23.

${ }^{53}$ See note 51 above where the governor used the term dret, which could refer to a tax. For the definition of dret in this period see A. M. Alcover and F. de B. Moll, Diccionari Català-Valencià-Balear (Institut d'Estudis Catalans, 2001-2002), <http://dcvb.iecat.net/> .

${ }^{54}$ Nadia Zeldes, "The Legal Status of Jewish Converts to Christianity in Southern Italy and Provence," California Italian Studies 1 (2010), 1-17: 12; see also Danielle IANCu, "Encore les néophytes. Réflexions sur la tallia neofitorum (1503-1512)," REJ 166 (2007), 265-272.

${ }^{55}$ Yosef KaPlan, "Between Christianity and Judaism in Early Modern Europe: the Confessionalization Process of the Western Sephardi Diaspora," in Judaism, Christianity, and Islam in the Course of History; Exchange and Conflicts, eds. Lothar GALL \& Dietmar WiLLowert (Munich: R. Oldenbourg, 2011), 307-341: 312. 
By relinquishing $20 \%$ of their loan investments, the conversos potentially avoided accusations of usury, now that they were Christians. While medieval usury laws prohibited Christians from charging interest on loans to other Christians, Jews would be punished for "usury" (through fines or confiscation of loans) only if the interest they charged exceeded the legal rate of $20 \% .{ }^{56}$ Effectively, the conversos transferred to the Crown the interest on outstanding loans which they had made prior to their conversion.

In addition to paying the donatio, the Majorcan conversos also purchased royal pardons to free them from specific crimes or liabilities, individually and as a collective, just as they did prior to their baptism. For instance, in 1395 the community paid 460 florins for a royal pardon that released the guarantors of conversos who fled the island illegally from paying exorbitant fines, and protected illegal exiles who chose to return. ${ }^{57}$ Conversos, then, found themselves collectively burdened by the same kinds of financial obligations as when they were Jews and members of an aljama: obligated to pay a significant percentage of their assets to the Crown, obligated to pay for royal protection and assistance in recovering loan investments, and obligated to pay for pardons that, perhaps counterintuitively, alleviated financial pressures.

\subsection{Collective Debt}

There was another, daunting financial burden, in addition to paying the donatio and other pardons, that the Majorcan conversos inherited from their Jewish past, and which kept them bound to it: the former

\footnotetext{
${ }^{56}$ Aljamas had, in the past, bribed the king not to fine them when individual creditors in the community charged more interest than the legal rate. For instance, in 1290, King Alfons effectively took a bribe of 37,000 sous from the Majorcan aljama for his abandonment of proceedings against them for usury (IsAacs, The Jews of Majorca, 31); cf. the 20,000 sous compositio paid to King Jaume by Valencian aljamas in order to stop investigations of usury among them, in Mark D. MeYerson, Jews in an Iberian Frontier Kingdom: Society, Economy, and Politics in Morvedre, 1248-1391 (Boston: Brill, 2004), 188. For more on moneylending and issues of usury, see ibid. chapter 4, "The Yoke of Usury."

${ }^{57}$ Conversos who did not pay the tax for the pardon could not benefit from it (ACA CR 1998, 118v-120r, October 11, 1395; 1999, 151v-152r, October 15, 1395; 2000, 124r-v, December 18, 1395).
} 
aljama's collective debt. In the decades leading up to 1391, many Jewish communities in financial straits had to borrow money in order to meet the constant fiscal demands of King Joan and his father, King Pere, or sometimes to meet urgent communal needs. This was typically done by "selling" censals, or annuities whereby investors lent capital to the debtor, in this case the aljama, in exchange for perpetual, fixed, annual interest payments at relatively low rates, which the aljama raised through internal taxes. ${ }^{58}$ In 1389, King Joan had ordered the secretaries of the Majorcan aljama to sell censals to provide funds for the governor of Sardinia as well as for expenses associated with the general Cortes. ${ }^{59}$ By August 1391, the Majorcan aljama had accrued a total debt worth 24,000 pounds through selling censals, paying 1,500 Barcelonan pounds in annuities to creditors, censalers, some of whom were citizens of Majorca, others of Barcelona. ${ }^{60}$

When the institution of the aljama came to an end, its creditors scrambled to reclaim their investments while they could still identify its former constituents, baptised or not. ${ }^{61}$ The collective assets of the former aljama, such as real estate or charitable investments, could not be used to repay its debt since King Joan had seized them all. After lengthy

${ }^{58}$ For more on the censal, see Arcadio García SAnz, "El censal," Boletín de la Sociedad Castellonense de Cultura 37 (1961), 281-310. In some cases, the king instructed an aljama to sell censals in order to subsidize his affairs, and allocated fixed royal revenues to that aljama to help pay the annuities; in such cases the aljama functioned as a middleman in procuring loans for the king. For instance, King Joan's father, King Pere, compelled the Majorcan aljama to provide him with a subsidy by selling censals that obligated it to pay over 443 pounds in annuities. However, Pere helped the aljama pay these annuities by allowing it to collect royal notarial rents from the city as well as villages, i.e. the annual payments notaries made to the Crown to be permitted to practise their trade (ACA CR 1996, 37r, October 31, 1392).

${ }^{59}$ In that case, King Joan did not provide the aljama with any help to pay the annuities. ACA CR 1872, 175r-v (nd, 1389); 1873, 23v (May 10, 1389); 1873, 33r (May 20, 1389); ARM LR 37, 162r-v (June 2, 1389); ACA CR 2000, 181v-184r (November 18, 1395) mentions that Joan's father, Pere, ordered the aljama to sell censals to provide him with subsidies.

${ }^{60}$ ACA CR 1995, 138v-139r (August 9, 1392): “The conversos are greatly indebted to creditors of Barcelona and Majorca... debts which the conversos incurred, in part, for the king's own necessities;" 1996, 40v-41r.

${ }^{61}$ Regarding the creditors' supplication to King Joan concerning the former aljama of Majorca see ACA 1995, 61r, April 7 (?), 1392. 
negotiations between the converso procuradors and the creditors, mediated by Jaume Pastor, an official of the royal treasury, it was determined that every converso and Jewish household had to contribute 10 sous, 6 diners per pound of the total value of their assets to pay off the former aljama's debt. ${ }^{62}$ Conversos therefore had to relinquish $52.5 \%$ of their assets to the creditors, in addition to paying $20 \%$ of their loan investments to the king, and contributing to collectively purchased pardons. The patrimony of some Majorcan families must have been stripped by almost three-quarters, and at a time when they were still suffering economically from the blow of 1391; not only were household valuables and business merchandise plundered during the attack on the Jewish quarter, but the livelihood of many was disrupted for a long time afterwards.

By way of comparison, the Valencian conversos were taxed 7 sous, 6 diners per pound, or $37.5 \%$, to settle the debt of their own former aljama. When they were still short 500 pounds from repaying their debt in 1394 , the king ordered the municipality to assist them from city taxes. ${ }^{63}$ There is no evidence that any such assistance materialized in Majorca. In Barcelona, the debt repayment was managed through a very different method: confiscating the goods of, and collecting the debts owed to Jews and conversos who died intestate, were minors, or were absent from the city; and taxing the sale of real estate located in the Jewish quarter at 10 sous per pound, or 50\%. ${ }^{64}$ In contrast, any converso absent from Majorca without a royal license was essentially treated as an apostate and their property confiscated by the Crown, so it could not be used toward the

${ }^{62}$ ARM AH S-31, 46r-59r (January 30, 1393), 49v, 51v, 52r. This document is not an actual contract between conversos and their creditors but is rather the record of a judicial investigation, the testimonies of which mention the tax and remission rates.

${ }^{63}$ Hinojosa Montalvo, The Jews of the Kingdom of Valencia, 466-467, no. 238. Roth cites Hinojosa on the "financial difficulties" faced by the Valencian conversos after the violence, who still had to negotiate "payment of various taxes and expenses to the government” (in his "1391 in Aragon, Catalonia, Valencia, and Majorca,” 52).

${ }^{64}$ Recently, Pons i Casacuberta published a study of the royal commission created to oversee the repayment of the former aljama of Barcelona's debt. Although the commission had the right to levy a head tax, it does not appear that they did (Pons I CASACUBERTA, "La Comissió creada pel Rei Joan I i la Reina Violant," 120 and 131). One out of the three royal officials who comprised the commission for Barcelona also handled the debt repayment Majorca: Jaume Pastor, who is called "commissioner" of the royal treasury (ACA CR 1997, 170v, January 28, 1395). 
debt repayment, as it would have been in Barcelona. In each of these cities, the Crown authorized individual conversos and Jews to sell their houses in order to pay their debts. ${ }^{65}$ In Majorca, King Joan demanded a percentage of the profits of the sale of any house sold that had belonged to a Jew or converso. ${ }^{66}$

In order to meet their collective financial obligations, conversos needed to organize themselves in the fastest and most efficient way possible, so they replicated the administrative framework and taxation methods of the aljama, which were familiar to royal officials as well as the Jewish and converso taxpayers. ${ }^{67}$ Like aljama secretaries, the converso procuradors were responsible for the community's fiscal administration in addition to representing and defending their community vis-à-vis king and creditors. They also established separate tax assessors and auditors to carry out the collection and transfer of the debt-tax. ${ }^{68}$ In 1393, after the year-long royal moratorium on the conversos' debt repayment had expired, the assets of every converso household were meticulously appraised in at least three successive tax assessments, all under the watchful eye of Jaume Pastor, who recorded everything in notebooks that, although repeatedly referenced, have not yet surfaced in the archives. ${ }^{69}$ The property assessed included real estate, commercial investments,

${ }^{65}$ For instance, in Majorca, the converso Francesc Fuster, formerly called Samuel Natjar (from a well-established local family), indicated that he had allocated certain houses to the creditors of the aljama, probably because he did not have sufficient liquid assets to pay his tax assessment (ACM Protocols Notarials, 14666, Joan Clavell, loose folio, September 2, 1393). For the king authorizing the sale of houses in Valencia, see Hinojosa Montalvo, The Jews of the Kingdom of Valencia, 395, no. 124.

${ }^{66}$ ACA CR 1997, 81r (April 3, 1394). In the case of exiles' houses, the creditors could take the percentage that would have been owed to for the debt tax, and the rest went to the Crown. ACA CR 1996, 127r (June 12, 1393), 153v-154r (August 22, 1393).

${ }^{67}$ The same organization occurred in Provence when the conversos were separately taxed there. See Zeldes, "The Legal Status of Jewish Converts to Christianity," 12.

${ }^{68}$ For a reference to auditors and other conversos entrusted to impugner the debt tax collection, see ACA CR 2266, 161v-162r (January 18, 1403). The taxadors varied though the years. See e.g. ACA CR 1996, 160v-161r, 163v-164v (September 16, 1393); On the arrangement between the conversos and the censalers of the former aljama in Valencia, see Hinojosa Montalvo, The Jews of the Kingdom of Valencia, 393-395, no. 123, and 412-417, no. 153.

${ }^{69}$ ARM AH S-31, 46r-59r (January 30, 1393). The initial agreement on the rate of taxation must have occurred in 1392. For a reference to the books recording tax 
merchandise, dowries, ${ }^{70}$ and loans. In order to facilitate the assessments, the king ordered notaries to provide the procuradors with an account of all commercial transactions (including loan or commenda investments, partnerships, etc.) that involved any Jew or converso, whether or not they were currently resident on the island. ${ }^{71}$ The entire process of collecting the debt-tax followed prior methods typically employed by aljamas: the per sou i lliura method of assessment, the collaboration of the procuradors with royal officials, and the disclosure or surrender of records indicating the assets of the community and its members to agents of the royal fisc. ${ }^{72}$

Proper distribution of the debt burden through multiple tax assessments, or talles, proved difficult enough, but collecting and redistributing those amounts presented their own problems as well. Nor was the tax collection simply a matter of collecting cash payments and transferring them to the creditors. The titular transfer of real estate, rents and loans owed to conversos comprised a substantial portion of the repayment. The transfer of titles was common in this period and probably symptomatic of coin shortages in the late Middle Ages, but it in this case it also reflects the extent to which Majorcan Jews and conversos had their capital tied up in loans or commercial investments. The logistics of the debt settlement were further complicated by the fact that there were two distinct groups of creditors, or censalistas, with whom different agreements were reached: one composed of citizens of Majorca, the other composed of citizens of Barcelona, who held the greater share of the debt. ${ }^{73}$ Individual

assessments see ACA CR 160v-161r (September 16, 1393). On the one-year moratorium which King Joan granted to the conversos on all their debts see e.g. ACA CR 1995, 99r-v (May 30, 1392); ARM AH LR 39, 96r-v (June 22, 1392).

${ }^{70}$ The mapmaker and royal familiar Jaume Ribes, called Jaffudà Cresques before he converted (son of the famous Abraham Cresques), solicited the help of the king in staving off the taxadors from seizing part of his sister Francisca's dowry (ACA CR 1997, 59r-v, March 22, 1394).

${ }^{71}$ ACA CR 1996, 160v (September 16, 1393).

${ }^{72}$ On the per sou i lliura system see Meyerson, "Fiscal Servitude," chap. 3 in Jews in an Iberian Frontier Kingdom, 120. According to this system, individuals declared their assets on oath and the adelantats (a position assumed in this case by the procuradors) decided upon the rate they should pay according to their capability.

${ }^{73}$ The aljama's debt mimicked the municipal public debt in this respect, since Barcelonan citizens held a major share of the municipal debt, too. See Jordi MorelLó I 
creditors may have invested different amounts, acting independently or in association with others at different times, but after 1391 they acted collectively for the sake of recovering their investments.

In 1392 Joan des Valls, a delegate of the Barcelonan creditors, came to Majorca to negotiate a payment plan with the converso procuradors. The total amount owed to the Barcelonan contingent was around 15,000 pounds, but they granted a remittance of three sous per pound (or 15\%) of the principal, in addition to the interest. ${ }^{74}$ Payment would be made through a combination of cash and transferred titles to debts owed to conversos or Jews. A few months after this agreement was reached, there was a legal investigation into the comportment of Joan des Valls, who had been accused of secretly making an illicit deal with the procuradors, offering them a reduction in the total amount the conversos would have to repay the Barcelonan creditors if they repaid him, and him alone, the full principal of the particular censal that he had purchased from the Majorcan aljama, which was worth 1,000 sous, a relatively small percentage of the total debt. ${ }^{75}$ What the testimonies in this investigation illustrate so well is how the diplomatic skills and political relationships cultivated by converso leaders, like aljama secretaries, had important implications for the economic survival of the entire community.

The total amount owing to the Majorcan creditors was 9,500 pounds. Like their Barcelonan counterparts, they offered a remittance, albeit at a higher rate of four sous, six diners per pound, or $22.5 \%$ of the principal. ${ }^{76}$

BAGET, "Majorca i la seva dependència financiera del principat (segles XIV-XV). Estudi dels censalistes catalans," AEM 33 (2003), 119-169.

${ }^{74}$ ARM AH S-31, 52r (January 30, 1393). The conversos of Valencia received a remittance of 2 sous, 6 diners per pound (12.5\%) of the principal, and fourteen months' pension. HinososA Montalvo, The Jews of the Kingdom of Valencia, 413, no. 153. The conversos of Barcelona received a remittance of 4 sous per pound (20\%) plus one year's pension; the remittance was raised from the first agreement to 5 sous, 6 diners per pound, or $27.5 \%$, according to PoNs I CASACUBERTA, "La comissió creada pel rei Joan I i la reina Violant," 127. The remittances appear to have been brokered by Crown.

75 ARM AH S-31, 46r-59r (January 30, 1393).

${ }^{76}$ AHN Carp. 70, no. 4 (September 1, 1393), publ. Joan Rosselló Lliteras, Els Pergamins de la Cartoixa de Valldemossa (Palma de Majorca: Conselll de Majorca, 2000), 137-138. No mention is made of the interest owing. That the Majorcan creditors appear to grant a larger remittance than those of Barcelona may in part be due to the discrepancy in 
An agreement of September 1393 between the procuradors and the Majorcan creditors specified a threefold payment plan consisting of the titular transfer of certain principal houses of the Jewish quarter, of "recoverable" debts, and of rent payments in oil, grain and cash."

\subsection{The Trials and Tribulations of Tax Collection}

Once the terms of the debt settlement had been determined in 1393, the governor wrote to rural bailiffs directing them to compel debtors in their jurisdictions to repay the debts that individual conversos had ceded to Old Christian creditors. However, collecting these debts was no easy feat. In 1398, five years after the debt collections began, Bernat Buçot, representing the Barcelonan creditors, complained that 3,000 pounds worth of transferred debts still remained to be collected. ${ }^{78}$ The Crown experienced the same difficulties: in 1395 King Joan was informed that the four sous per pound still had not been paid, and that few of the debts confiscated from exiles had been collected, despite his incessant reminders for local officials to pursue these. ${ }^{79}$ Both Kings Joan and

the two currencies. In 1395, one sou of Barcelona was worth about 1.25 sous of Majorca (exchange value taken from ACA CR 1997, 169v-170r, January 28, 1395).

${ }^{77}$ AHN Carp. 70, nos. 3 and 4 (September 1, 1393), publ. Rosselló Lliteras, Els Pergamins de la Cartoixa de Valldemossa, 137-138. The houses must have been among the most impressive in the Jewish quarter since they had belonged to Magaluff Doscha, deceased, who belonged to one of the aljama's elite families. The term "recoverable" is not defined but presumably it refers to debts that could be collected relatively easily. The term also appears in royal letters in which King Joan accedes to the conversos' request to pay the donatio partly through recoverable, and partly through irrecoverable debts, allowing the conversos to use 24,000 pounds worth of recoverable debts to pay the debttax. ACA CR 1996, 40v-41r (November 23, 1392). An example of rents transferred to creditors: Pere Onis, called Jacob de Manacor before he converted, had to pay 99 pounds, 18 sous and 6 diners to Pere and Felip Serra, two brothers who numbered among the Majorcan creditors named in the payment agreement of September 1393. As part of this payment, the governor ordered the bailiff of Montuiri to have certain residents of his district pay annual rents to the Serra brothers, rents which those residents had, in the past, paid to Pere Onis (ARM AH 66, 112r-v, January 8, 1394; the document in which the procuradors informed Pere Onis of his assessment was dated January 9, 1393).

${ }^{78}$ ACA CR 2263,106v-107r (September 3, 1398).

${ }^{79}$ ACA CR 1998, 38v-39r (March 20, 1395). For King Joan ordering that the 
Martí repeatedly chastised royal officials for their laxity in enforcing the liquidation of these debts, but with little success, receiving reports that the debtors constantly alleged that they had already paid or that they were totally destitute; or so much time had passed since the loan was made, that no one who might be held responsible to repay it could be found. For their part, rural bailiffs, no doubt wary of provoking further unrest among the still-disgruntled inhabitants of their districts, may have evaded royal orders to proceed with collections.

The difficulties with collecting the debt tax were not relegated to the rural debtors. The converso procuradors and tax administrators faced the same internal challenges that Jewish aljama officials notoriously had to contend with when collecting taxes within Jewish communities: haggling over rates of taxation, outright refusals to pay, and various forms of tax evasion. As late as 1407, fourteen years after the assessments, King Martí was still pressing the procuradors and royal officials to compel recalcitrant conversos to pay their share of the debt-tax. ${ }^{80}$

Tax evasion was one of the main reasons behind the repeated assessments or talles in 1393. When the procuradors solicited permission for a third talla in September of that year they explained that after each of the first two, certain conversos were "discovered" to have been left out, who in fact were obligated to contribute. ${ }^{81}$ Evidently conversos employed the same manoeuvres to evade taxes as Jews did before 1391: moving from one jurisdiction (or aljama) to another, sometimes claiming to each side that they already paid taxes in the other location, or keeping some of their assets in a different jurisdiction from the one in which they resided so

debts and donatio be collected, and on the difficulties, see: ACA CR 1997, 137v-138r (September 24, 1394); 1998, 36v-37r (March 20, 1395); 1999, 105v-106r (November 16, 1395). Royal correspondence exhibits a greater concern over collecting confiscated assets than the donatio, probably for their greater revenue potential.

${ }^{80}$ ACA CR 2269, 152r-v (July 1, 1407).

${ }^{81}$ ACA CR 1996, 161v, 164r-v (September 16, 1393). At least one of the censuses must have been carried out before January 1393, possibly some time in 1392 . The third (and final) assessment was conducted after September 1393, and complaints made by individual conversos relating to tax collection surface early in 1394. See ACA CR 1997, 59r-v (March 22, 1394). These censuses had been recorded in a book by the procurador Antoni Agost, formerly Moxi Natjar. 
that they could not be tracked. ${ }^{82}$ Similarly, the procuradors complained of conversos concealing their possessions in various ways so that they could not be assessed, keeping their merchandise in North Africa, or exporting some of their Majorcan assets through commercial and other means in order to avoid paying the tax. ${ }^{83}$ The commercially savvy could employ financial mechanisms typically used in long distance trade to make their assets difficult to trace, by shifting their location or titular ownership, for instance. Such tactics were one motivation behind the royal prohibitions, issued shortly after the revolt, against any transfer of converso property. ${ }^{84}$ Furthermore, some individuals managed to avoid being assessed entirely, by leaving the island while the talles were being carried out. ${ }^{85}$

A rise in the number of royal licenses issued to conversos beginning in 1394 for travel between Majorca and Valencia, precisely at the time that they were being taxed, points to mobility as another tax evasion strategy. ${ }^{86}$ It would have been easier to get a license to travel within the kingdom than without. Many Majorcan conversos, particularly merchants, had family and commercial connections in Valencia, which facilitated their travel, and the relocation of their assets there. In this light, we might also reconsider the significance of the exodus of Jews and conversos to North Africa in the years following 1391, and ask whether, in some cases, these exiles were economically rather than religiously motivated. After all, it had happened before: in 1357, when King Pere requested additional subsidies from the Majorcan aljama to finance the war against

${ }^{82}$ On Jewish tax evasion in the Crown of Aragon during the decade prior to 1391 see GuERSON, "Seeking remission," 33-52.

${ }^{83}$ ACA CR 1996, 161v, 171r-v (September 16, 1393).

${ }^{84}$ For the prohibition against any kind of alienation of converso-owned properties see, ARM AH 419, 104 bis (October 10, 1392); 117 (July 2, 1392), also publ. BSAL 8 (1899), 443; 117 bis (January 31, 1393); for the royal letter ordering the latter public announcement see ACA CR 1996, 39v (November 23, 1392).

${ }^{85}$ In 1394 the lieutenant governor Berenguer de Montagut chastised the bailiffs of rural parishes who allowed conversos to leave the kingdom through their districts, to the injury of those conversos who remained and had to pay the communal debt (ARM AH 66, $168 \mathrm{v}$, March 28, 1394).

${ }^{86}$ See ARM AH G5 for licenses to go to Valencia, which continue to be issued frequently in subsequent years. For traffic in the opposite direction, of Valencian conversos immigrating to Majorca, see ACA CR 2001: 27r (November 24, 1395). 
Castile, its representatives responded that more than forty Jews had already emigrated to the Maghreb as a result of his constant exactions. ${ }^{87}$ Interestingly, in 1393 the Jewish community of Palermo complained of many foreign Jews coming to their city, who were likely relapsed conversos from the Crown of Aragon. Perhaps they were conversos from Barcelona, Valencia or Majorca who were motivated to leave when the tax levies began. ${ }^{88}$ All this is to say that baptism did not stop conversos from exploiting the same established relationships and strategies that had been available to them as Jews, as they struggled to keep their head above water. If anything, baptism may have made such survival strategies more common, although recast their meaning in religious terms.

\section{Royal Policy, Collective Debt and Jewish Identity}

The evasion tactics of rural debtors and converso taxpayers were but one of many factors that prevented the community from clearing its debt. There were also delays as a result of investigations into alleged fraudulent behaviour, such as tax administrators hoarding the cash collected, ${ }^{89}$ or

${ }^{87}$ Jorge Maíz Chacón and Lluís Tudela I Villalonga, "Els mercaders jueus mallorquins a meitat del segle XIV," in La Mediterrània de la Corona d'Aragó, segles XIII-XVI \& VII Centenari de la Sentència Arbitral de Torrellas, 1304-2004: XVIII Congrés d'Història de la Corona d'Aragó, València 2004, 9-14 setembre (Valencia: Universitat, 2005), vol. I, 1129-1148: 1130.

${ }^{88}$ Nadia Zeldes, "Catalan Jews and Conversos in Sicily. Migration, Cultural Encounters and Social Conflict," in La presència catalana a la Mediterrània medieval: noves fonts, recerques i perspectives (forthcoming; my thanks to the author for allowing me access to the article).

${ }^{89}$ For example, King Martí ordered a royal investigation regarding money collected for the debt tax which converso administrators continued to hold in their possession a decade after the assessments had been completed, and also to check if any of it pertained to the royal fisc (ACA CR 2266, 161v-162r, January 18, 1403). There was at least one other case of hoarding of communal funds: Antoni Agost, called Moxi Natjar before his conversion, a former aljama secretary, treasurer, and member of a prominent Majorcan Jewish family, had been involved in negotiating, assessing, and collecting the debt-tax as one of the converso procuradors in 1393, and held some of the tax money in his possession. Antoni was murdered sometime between September and December 1393, most likely in connection to his involvement with converso finances (ACA CR 1997, $165 \mathrm{r}-\mathrm{v}$, January 1,1395$)$. When the community of conversos requested this cash from 
the shady deal between the procuradors and Joan des Valls. Moreover, the king's continuing sense of ownership over converso property led him to contest certain transfers of real estate and other assets to their creditors as part of the debt settlement, which resulted in legal disputes that further hindered repayment of the aljama's debt. ${ }^{90}$ With these and other impediments, it is not clear whether the creditors ever received their due. What is more pertinent to this discussion, though, is the fact that prolonging the community's indebtedness meant prolonging its need to function as a single social unit for the purposes of financial administration. ${ }^{91}$

As a community, the conversos were forced into a situation that kept them bound to certain "Jewish" fiscal dynamics at least through to the end of King Martí's reign (1410) and probably beyond. The conversos of Majorca were not alone in this respect. In Valencia, in 1420, there was still a legal dispute between two groups of conversos concerning their debt

his heirs after his death, the heirs would not relinquish it, offering instead to pay the equivalent value in debts that were owed to his inheritance. The case went to the king, who ordered that Antoni's heirs surrender any cash that pertained to the debt-tax (ACA CR 1996, 179v, December 2, 1393).

${ }^{90}$ The biggest locus of dispute was the houses belonging to conversos or Jews who had fled the island, since the king had claimed these for himself. See e.g., ACA CR 1996, $127 \mathrm{r}$ (June 12, 1393); 153v-154r (August 22, 1393), in which King Joan ordered that from the proceeds of the sale of exiles' houses, should be deducted any debts or pensions tied to them, then a portion given to the converso procuradors for the debt settlement (this would have been in accordance with the tax assessments) and the remainder to the royal treasury (ACA CR 1996: 129v, June 12, 1393). A few months later the king instructed Mateu de Llosch to return to the converso procuradors all the houses he had confiscated so that they might be factored into the tax assessment, while presumably the Crown would collect the remainder of proceeds from their sale (ACA CR 1996, 163v-164r, September 16, 1393; cf. ACA CR 1997, 81r, April 3, 1394).

${ }^{91}$ In his article on the converso confraternities in Valencia at the turn of the fifteenth century, Jaime Castillo Sainz similarly suggests that financial obligations stemming from the former aljama as well as new ones to the king compelled the first generation of conversos there to remain a separate and cohesive group, but that in any case it would have been socially and culturally difficult for them to do otherwise; however, in his view, by the second generation, financial exigencies were the only reason conversos needed to congregate as a single collective, and most conversos would have preferred not to be part of a community. Jaime CASTILlo SAINZ, "De solidaritats jueves a confraries de conversos," Revista d'Història Medieval 4 (1993), 183-205: 203. 
tax. ${ }^{92}$ The extent and duration of the conversos' collective indebtedness is significant, because it anchored the conversos, collectively, within a cluster of diverse financial relations that were continuous with their former Jewish identity: economically vulnerable; a separate social group with its own administration, and fiscally separate from the rest of Christian society; burdened by high taxes; making special contributions to the royal coffers in order to maintain the Crown's beneficence and protection.

The distinct relationship that had existed between Majorcan Jews and the Crown persisted with conversos after 1391. King Joan continued to treat conversos as a separate social unit, notably for financial purposes, an attitude which continued under King Martí. This royal policy, together with collective fiscal obligations forced the conversos to remain a separate collective analogous to the aljama, with its own administration. The kings referred to them as a universitas, the same term used for the municipal corporate body. ${ }^{93}$ As such, conversos remained entrenched in effectively the same social, economic and institutional structures as when they were Jews, employing the same survival strategies to negotiate between the demands of kings, creditors, and their own needs. This situation perpetuated a group identity that was conspicuously rooted in its Jewish past, and not only lent itself to continued Jewish affiliation, but quite possibly promoted it.

The first years following 1391 were a formative period, when conversos found themselves in a what we might call a liminal space, no longer a Jewish community, yet still socially, economically and familially linked to their Jewish neighbours, and still separate from Old Christian society. They continued to marry and apprentice with one another. Conversos also shared, and had to defend, other collective interests, beyond the fiscal, such as the welfare of their community, providing care to the sick, charity to the poor, and proper burials for the dead - projects which, both in Jewish and Christian

\footnotetext{
${ }^{92}$ Hinojosa Montalvo, The Jews of the Kingdom of Valencia, 500-501, no. 316.

${ }^{93}$ For example, a rubric of one of King Joan's letters reads pro universitate conversorum (ACA 2000, 124r-v, December 18, 1395). King Martí also used the term universitate for the taxpayers of the ciutat in ACA 2264, 135v (August 20, 1399). In addition, Martí referred to the conversos as a comunitas in ACA CR 2269, 152r-v (July $1,1407)$.
} 
contexts, tended to be carried out under the auspices of a confraternity. Hence the reconfiguration of collective institutional frameworks and a corresponding group identity coalesced, at the turn of the fifteenth century, in the foundation of an exclusively converso charitable brotherhood, the confraternity of Sant Miquel. Establishing this confraternity rendered their de facto corporate status de iure, and reinforced their sense of belonging to a new social group with distinct needs. Sant Miquel, like other Christian or Jewish confraternities, not only expressed, but also cemented collective bonds and identity. In a separate article I have discussed the continuities between the converso confraternity and the former aljama in terms of their administrative structures and welfare provisions; at the same time, it resembled Old Christian confraternities, or perhaps other corporate institutions. $^{94}$

A final word regarding the social separation of the converso community, and a call for future study: it would be informative to compare the situation of post-1391 conversos in the Crown of Aragon with the mass conversion of the Jews of Southern Italy under Angevin rule, as a result of Dominican pressure, at the end of the thirteenth century. Archival records dating between 1290 and 1294 reveal the transformation of Jewish communities to communities of neofiti that remained separate from the rest of Christian society, and continued Jewish practices, for over two hundred years. ${ }^{95}$ Like the post-1391 converso communities in the Crown of Aragon, or in Provence and southern Italy at the turn of the sixteenth century, the thirteenth-century neofiti were also referred to as a universitas, implying a legal collective entity, to extent that they had separate representatives in the civic administration of Trani. ${ }^{96}$ However, it is not clear whether the neofiti experienced collective financial burdens similar to the conversos a century or two later, or whether the neofiti also had to repay old communal debts like the conversos of Majorca, Barcelona and Valencia did. Whereas the conversos of Majorca were

${ }^{94}$ Natalie Oeltuen, "A converso confraternity in Majorca: La Novella Confraria de Sant Miquel," Jewish History 24 (2010), 53-85.

${ }^{95}$ Joshua STARr, "The Mass Conversion of Jews in Southern Italy (1290-1293)," Speculum 21 (1946), 203-211: 206-210.

${ }^{96}$ ZeLDES, "The Legal Status of Jewish Converts to Christianity," 3-4, 11. 
exempt from municipal taxes only for nine years, ${ }^{97}$ and had to contribute to the cost of pardons and the donatio, thirteenth-century neofiti were exempt from paying all taxes for their lifetime. It is not known whether the neofiti also had to repay old communal debts like the conversos of Majorca, Barcelona and Valencia did.

The study of notarial and royal chancery archives in Majorca suggests that baptism did not fundamentally change the collective organization of conversos in the first two or three generations. On the contrary, it introduced a set of economic circumstances which, in many respects, forced them to continue their communal lives essentially unchanged. It did not change who they owed money to, whom they were loyal to, who they worked with, and how they took care of each other. How, then, or when, we might ask, did it change who they were ${ }^{98}$ ?

Recibido: 02/09/2012

Aceptado: 29/05/2013

${ }^{97}$ ACA CR 1996, 172v-173r (September 16, 1393).

${ }^{98}$ This article stems from my doctoral dissertation on the conversos of Majorca, 1391-1416. I thank my supervisor, Mark Meyerson, at the University of Toronto, and the helpful staff at the archives in Majorca and Barcelona. I am especially thankful to the late Yom Tov Assis for having invited me to present the original version of this paper as a Hispania Judaica seminar while a postdoctoral fellow at the Hebrew University of Jerusalem in 2012, where I was sponsored by Yosef Kaplan. During this period I benefited from the generosity of the Bloomfield family and Lady Davis fellowship Trust, which provided me with the funds and time to write. I am also grateful to Kenneth Stow, Claude Stuczynski, Alexandra Guerson and particularly Nadia Zeldes for their feedback, as well as to the anonymous reviewers of Sefarad. Last, but not least, the meticulous critique of Jaume Riera contributed much to the improvement of this article. 